\title{
Strategie migracyjne Polaków po 2004 roku. Przypadek Szkocji
}

\author{
Monika Gacek ${ }^{1}$
}

\begin{abstract}
:
Migration strategies of Poles after 2004. Case study of Scotland. The topic of this paper is: the migration strategies of Poles after 2004. The example of Scotland. Paper is based on 25th interviews with Polish migrants in Edinburgh, literature about migrations and reports from Centre of Migrations Research $(C M R)$ in University of Warsaw. Paper contents conclusions from interviews which are compared to research about all Polish migrants in Great Britain. What is more, paper included more specific questions about living in United Kingdom, social help, opinion about British people, relations between Polish migrants, plans for future and more. At first, most of Polish migrants were living in England but now it is changing, they going to other parts of this country, like Scotland. That problem seems to becoming more and more important in time. Migrations to UK after 2004 are still actual topic because the number of Polish people living in there is still rising and in a huge part it is equivalent with staying there permanently. British economy gains a lot on Polish migrants. They are very flexible and hardworking. Polish economy gain on them too, because of the money transferring to Poland to their families.
\end{abstract}

Keywords:

migrations, Polish diaspora in Scotland, migration strategies, United Kingdom, Scotland

\section{Streszczenie:}

Tematem artykułu sa strategie migracyjne Polaków w Szkocji po 2004 roku. Praca oparta została na wynikach dwudziestu pięciu wywiadów z Polakami mieszkającymi w Edynburgu, literaturze na temat migracji oraz raportach Ośrodka Badań nad Migracjami Uniwersytetu Warszawskiego. W artykule przedstawione zostaly wnioski wyciagnięte z wywiadów, a następnie porównane do badań na temat Polonii w Zjednoczonym Królestwie. Ponadto, artykut zawiera analize odpowiedzi na pytania dotyczace życia w Wielkiej Brytanii, pomocy socjalnej, opinii na temat Brytyjczyków, relacji między polskimi migrantami, planów na przyszłość oraz wiele innych. Początkowo większość polskich migrantów osiedlata się w Anglii, ale obecnie ulega to zmianie i migranci wybieraja inne części Zjednoczonego Królestwa, w tym Szkocję. Polacy tatwo integruja się w nowych miejscach zamieszkania oraz przystosowuja do wymogów rynku pracy. Ta kwestia okazuje się z uplywem czasu zyskiwać coraz większe znaczenie. Migracje do Wielkiej Brytanii po 2004 roku to wciąz aktualny temat, ponieważ liczba Polaków żyjących tam ciagle rośnie i w sporej części jest to równoważne z osiedleniem się na stałe. Brytyjska gospodarka wiele zyskuje dzięki pracy polskich migrantów. Sa bardzo elastyczni w kwestii wykonywanych zawodów oraz bardzo pracowici. Polskiej gospodarce również przynosi to korzyść, ze względu na transfery zarobków przesyłanych do rodzin w Polsce.

\section{Słowa kluczowe:}

migracje, Polonia w Wielkiej Brytanii, strategie migracyjne, Szkocja

Link do artykułu:

http://pogranicze.uni.opole.p1/biblioteka/docs/nr1/gacek_nr1.pdf

Standard cytowania (APA):

Gacek, M. Strategie migracyjne Polaków po 2004 roku. Przypadek Szkocji. Pogranicze. Polish Borderlands Studies, $n r$ 1, s. 106-116.

Wrazz wejściem Polski do Unii Europejskiej w 2004 roku, otworzyły się dla Polaków rynki pracy państw członkowskich. Prawo swobodnego przepływu pracowników stało się szansą na wejście na najbardziej rozwinięte rynki europejskie. Od tego momentu notowane jest nasilenie się migracji Polaków, którzy wykorzystując nowe unijne przywileje, opuszczają ojczyznę w poszukiwaniu lepszej przyszłości. Migracja ludności to przemieszczanie się $\mathrm{w}$ celu zmiany swojego miejsca pobytu, $\mathrm{z}$ języka łacińskiego migratio - wędrówka (Lewandowski 2010). Wyjazdy Polaków do krajów Unii mają w przeważającej części charakter zarobkowy.

$\overline{1}$ Monika Gacek: absolwentka stosunków międzynarodowych na Uniwersytecie Opolskim. Studentka Edinburgh College. 
Czynnik polityczny, który motywował dotychczas do wyjazdu, ustąpił miejsca ekonomicznemu. Duże możliwości i perspektywę sukcesu przesłania jednak rzeczywistość, w której dla coraz większej liczby Polaków, migracja zarobkowa to jedyny sposób na utrzymanie. Migracje przyczyniają się z jednej strony do wyrównywania poziomu życia oraz poprawy warunków bytowych, $\mathrm{z}$ drugiej strony, ceną za to jest nierzadko utrata kontaktu z bliskimi oraz poczucie wyobcowania w nowym miejscu. Wyjazdy te zmniejszają skutki wysokiego poziomu bezrobocia w Polsce, poprzez transfer zarobionych za granicą pieniędzy do ojczyzny, łagodzą następstwa kryzysu i poprawiają saldo bilansu płatniczego. W latach 2004-2009 polscy migranci przesłali do ojczyzny około 21 miliardów euro (Bera, Korczyński 2012). Kraj przyjmujący uzupełnia swoje braki na rynku pracy, może korzystać z kadry wykształconej na koszt innego państwa. Polscy pracownicy, nawet $\mathrm{z}$ wykształceniem średnim czy podstawowym, wykazują się kreatywnością i dużą efektywnością w pracy, o czym zagraniczni pracodawcy mieli okazję się przekonać. Charakterystyczną cechą polskich migracji jest fakt, że najczęściej z okresowych zmieniają się one w stałe. Decyzja o wyjeździe w celu zgromadzenia określonej sumy pieniędzy, zamienia się w stały pobyt oraz powoduje ściągnięcie do siebie rodziny (Rauziński 2010).

Według danych Głównego Urzędu Statystycznego, w roku 2004 do krajów Unii Europejskiej wyemigrowało łącznie 750 tysięcy Polaków, z czego najwięcej, bo aż 385 tysięcy do Niemiec, w dalszej kolejności do Wielkiej Brytanii - 150 tysięcy oraz do Włoch -59 tysięcy. Sytuacja na przestrzeni kolejnych lat zaczęła się gwałtownie zmieniać, gdyż już w roku 2007, liczba migrantów z Polski w państwach członkowskich UE wzrosła do 1,86 miliona, a w Zjednoczonym Królestwie do 690 tysięcy. Od 2006 roku najczęściej wybieranym krajem była Wielka Brytania. W 2010 roku przebywało tam około 560 tysięcy polskich emigrantów, co stanowiło 34,7 proc. migracji Polaków do państw Unii Europejskiej w tym roku (Główny Urząd Statystyczny 2011). Najwięcej Polaków mieszka w Londynie. Do większych skupisk Polonii zaliczamy również
Birmingham, Manchester, Liverpool, Glasgow, Edynburg i Dublin.

Interesującą część Zjednoczonego Królestwa stanowi Szkocja, którą określić można jako pogranicze kulturowe, zarówno ze względów historycznych, jak i z powodu współczesnych procesów imigracyjnych. Początkowo region ten był pomijany przez Polaków jako kierunek migracji, obecnie staje się coraz atrakcyjniejszym celem wyjazdu. W początkach okresu poakcesyjnego, migracja do Szkocji sprawiała pewne trudności, choćby z powodu braku bezpośrednich połączeń lotniczych z Polski i długiej podróży autokarem. Na niekorzyść Szkocji działa również dosyć trudny do zrozumienia „zmodyfikowany” język angielski używany przez Szkotów oraz deszczowa pogoda. Obecnie dzięki rozwojowi transportu lotniczego, koszty związane z migracją do Szkocji (zarówno finansowe, jak i czasowe) uległy radykalnemu obniżeniu. Istnieje też możliwość nadrobienia nieznajomości języka, uczestnicząc w kursach, prowadzonych za darmo bądź za uiszczeniem symbolicznej opłaty, w szkołach, które dopasowują zajęcia do preferencji uczęszczających. Poakcesyjne skupienie Polonii w Anglii rozprasza się więc na inne części Zjednoczonego Królestwa, szczególnie Szkocję i Irlandię Północną. Szkocja, dość otwarta i przyjaźnie nastawiona na przypływ obcokrajowców, doświadcza dużego napływu siły roboczej z Polski. Pierwsi polscy migranci w Szkocji znaleźli się na uprzywilejowanej pozycji, ponieważ istniały tam wielkie braki na rynku pracy, które Polacy zapełnili. Często pracodawcy, mając do wyboru swoich rodaków oraz Polaków, świadomie wybierali tych drugich. Obecnie sytuacja wydaje się zmierzać w nieco gorszym dla migrantów kierunku. W efekcie napływu dużej liczby obcokrajowców, Brytyjczycy zaczęli obawiać się o swoje stanowiska pracy, co wywołuje pewną niechęć ze strony ludności rodzimej i dyskryminację migrantów. Pracodawcy bardziej selektywnie podchodzą do kwestii zatrudniania obcokrajowców. Wszystkie negatywne skutki napływu ludności nie zmieniają jednak faktu, że coraz więcej Polaków decyduje się 
na osiedlenie w Szkocji. Znalezienie posady wymaga nieco więcej wysiłku i pracy nad sobą, w tym inwestowania w naukę języka, jednakże tamtejsze warunki życia są nadal na tyle zachęcające, że warto dołożyć wszelkich starań i odnaleźć się w tym kraju.

Celem tego artykułu jest wskazanie cech szczególnych Polonii w Szkocji, na przykładzie miasta Edynburg, w porównaniu z ogólnym obrazem polskich migrantów w Wielkiej Brytanii. Główne pytania badawcze dotyczą tego, jak wyglądają relacje między migrantami w Edynburgu, jak radzą sobie z przystosowaniem do nowych realiów, co sprawia im największą trudność w życiu na obczyźnie, od czego zależy proces ich integracji, jakie były motywacje do wyjazdu i jaki jest stosunek migrantów do powrotów.

W Wielkiej Brytanii migracje Polaków po wejściu do Unii Europejskiej określono mianem najbardziej wzmożonego i odczuwalnego napływu obcokrajowców od czasów wojny (Fihel, Piętka 2007). Patrząc wstecz, obecną migrację poakcesyjną $\mathrm{w}$ ciągu ostatnich kilkudziesięciu lat poprzedzały trzy etapy exodusu. Pierwszy okres to czas po II wojnie światowej, kolejny - to lata osiemdziesiąte i migracja solidarnościowa; trzeci - to początek lat dziewięćdziesiątych, kiedy zmienił się reżim polityczny (Lewandowski 2010). Dzięki temu, że nie wprowadzono ograniczeń w stosunku do migrantów z nowych państw członkowskich, jak i dużemu zapotrzebowaniu na brytyjskim rynku pracy, Wielka Brytania jawiła się, jako bardzo atrakcyjne miejsce dla migrantów. Liczba podań o uzyskanie osobistego numeru ubezpieczenia społecznego (National Insurance Number - NINO), który jest niezbędny do podjęcia pracy, czy ubiegania się o świadczenia społeczne, złożonych przez Polaków w Wielkiej Brytanii w latach 2003/2004 wyniosła 11,2 tys., plasując ich na dziewiątym miejscu wśród dwudziestu największych narodowości migrujących do Zjednoczonego Królestwa. W latach 2004/2005 liczba ta wyniosła 62,6 tys., co spowodowało, że Polacy znaleźli się na pierwszym miejscu, a w 2005/2006 - 171,4 tys., utrzymując tę pozycję (Fihel, Piętka 2007).

\section{Wywiady}

Przeprowadzono 25 wywiadów jakościowych, częściowo skategoryzowanych, na reprezentatywnej grupie, w której znajdują się migranci, którzy wyemigrowali do Edynburga stosunkowo niedawno (3 miesiące wcześniej), jak i mieszkający tam od 2004 roku. Połowa tej grupy wyemigrowała wcześniej do innych państw, głównie do Irlandii i Niemiec, ale również do takich krajów, jak Szwecja, Stany Zjednoczone, bądź inne regiony Wielkiej Brytanii (Londyn, Glasgow). Jest to grupa mieszcząca się $\mathrm{w}$ przedziale wiekowym 23-51 lat, z czego najliczniejszą część stanowią osoby w wieku około czterdziestu lat.

Zaczynając od powodów wyjazdu, w odniesieniu do ogółu migrantów, wyznacza się trzy główne kategorie motywacji wyjazdowych. Najliczniejsza grupa to wyjeżdżający w celu znalezienia lepszej pracy i perspektyw na życie (49 proc.). Kolejna - to osoby, poszukujące nowych doświadczeń zarówno w pracy, jak i życiu (27 proc.). Ostatnia - to ludzie, dla których wyjazd jest koniecznością (24 proc.) (Milewski, Ruszczak-Żbikowska 2008). W przypadku motywacji wyjazdowych grupy ankietowanej wEdynburgu, wyróżniają się dwie grupy: pierwsza i liczniejsza to osoby, które do wyjazdu zmusiła trudna sytuacja materialna i brak perspektyw w ojczyźnie. Zaliczają się do niej starsi uczestnicy wywiadów, w wieku powyżej 35 lat. Grupa druga to osoby do 35 roku życia, przyjeżdżający głównie w celu zdobycia nowych doświadczeń, znający język, z chęcią poznania nowego kraju, podjęcia nauki. Pierwsze grono, jako powód wyboru Edynburga, najczęściej wskazuje na pomoc rodziny, która przebywała tam wcześniej i wspomogła ich na starcie. Pozostali uczestnicy wywiadu to najczęściej osoby stanu wolnego, często bez doświadczenia zawodowego, wyjeżdżające po ukończeniu szkoły średniej, bądź osoby, które migrowały wcześniej do innych państw. Ta część migrantów od początku zdana była wyłącznie na siebie. Decyzję o wyborze Edynburga podjęli ze względu na rekomendacje studentów, którzy opisywali Szkocję na stronach internetowych, znajomość języka, jak też położenie i piękną okolicę. 
Ogólnie panujący pogląd, że integracja nie sprawia polskim migrantom większych problemów. Zgodnie z uzyskanymi odpowiedziami, 37 proc. deklaruje większy kontakt $\mathrm{z}$ osobami obcych narodowości, niż z Polakami, a 35 proc. jednakowy kontakt zarówno z Polakami, jak i obcokrajowcami. Wśród migrantów zaledwie jedna czwarta jest w Wielkiej Brytanii bez rodziny. Około jedna trzecia znajduje się tam ze współmałżonkiem/ partnerem, a jedna piąta $\mathrm{z}$ rodzeństwem. Taki układ wpływa też po części na zamykanie się Polonii we własnym gronie. Odsetek związków czy małżeństw z obcokrajowcami wynosi tylko 6 proc. Jednakże występuje tendencja, zgodnie z którą dłuższy pobyt zwiększa czterokrotnie odsetek zawieranych związków mieszanych (Milewski, Ruszczak-Żbikowska 2008).

W wywiadzie natomiast starano się zbadać nieco głębiej kwestie więzi społecznych. Zarysowały się bowiem pewne trudności $\mathrm{w}$ procesie integracji, $\mathrm{w}$ tym problem odnajdywania się $\mathrm{w}$ nowym społeczeństwie. Zaobserwowano zależność, która zmusza do ponownego przywołania powyższego podziału na dwie grupy. Szybsza integracja występuje w grupie młodszej, głównie dzięki znajomości języka i otwartości na nowe znajomości. Integracja $\mathrm{w}$ grupie starszej ogranicza się do kontaktów w kwestiach zawodowych, czasem towarzyskich. Niekoniecznie jest to wynikiem niechęci czy uprzedzeń, lecz bariera językowa jest dla starszej grupy migrantów na tyle wstydliwa i trudna do pokonania, że zmusza ich do ograniczenia kontaktów w grupie rodaków.

Uczestnicy wywiadu nie mówią jednoznacznie, czy odczuwają niechęć, czy pozytywne nastawienie ze strony Szkotów. Ograniczają ten stosunek do konkretnej grupy społecznej. Największą niechęć odczuwają ze strony grup z podstawowym wykształceniem, nie do końca zorientowanych we współczesnym świecie, którzy obawiają się o swoje miejsca pracy. Zaznaczają też, że negatywne postrzeganie zwiększa się wraz $\mathrm{z}$ napływem coraz większej liczby migrantów. Rzutuje to na wzrost uprzedzeń do osób innych narodowości. Ludzie z wykształceniem doceniają wkład imigrantów w brytyjską gospodarkę. Jak stwierdzają uczestnicy wywiadu, multikulturowość tego miejsca nie idzie $w$ parze $z$ akceptacją innych narodowości, a Szkoci nadal mają duży problem $\mathrm{z}$ rasizmem. Biorąc pod uwagę występującą tam ogromną tolerancję $\mathrm{w}$ stosunku do środowisk homoseksualnych i subkultur, kwestia imigrantów powinna wyglądać nieco inaczej. Jednym z powodów takiego stanu rzeczy może być mocno ugruntowane $\mathrm{w}$ nich postrzeganie siebie, jako przede wszystkim Szkotów, nie Brytyjczyków, świadomość własnej kultury i odmienności, kultywowanie zwyczajów, jak np. noszenie kiltów i gra na dudach.

Konfrontując wyniki wywiadów $\mathrm{z}$ informacjami o całej o Polonii w Wielkiej Brytanii, uwidacznia się rosnąca niechęć pewnych grup społecznych w stosunku do Polaków, która $\mathrm{z}$ drugiej strony nie jest na tyle widoczna i uciążliwa, by skłaniała do szybszego powrotu czy zaprzestania osiedlania się. Odzwierciedlają to odpowiedzi na pytanie, czy Szkocja wydaje się miejscem przyjaznym dla migrantów. Zdecydowana większość, bo aż 80 proc. uznało je za takie, jednakże nie przekłada się to na atrakcyjność tego obszaru, jako miejsca stałego zamieszkania, ponieważ nikt z uczestników wywiadu nie chciałby tam mieszkać na stałe.

Na pytanie: czy różnice kulturowe między Polską a Wielką Brytanią są uciążliwe, tylko trzy osoby odpowiedziały twierdząco. Większość uważa, że przyzwyczaiła się a zarazem, że mieszkańcy Wielkiej Brytanii nie posiadają zbyt wielu odmiennych tradycji kulturowych. Rodacy wskazują na to, iż Brytyjczycy nie obchodzą świąt, a jeśli już, to nie czynią tego w takim wymiarze, jak Polacy. Ich życie nie jest tak podporządkowane religii. Każdy robi to, co w danym momencie sam uważa za stosowne, nie zwracając uwagi na ogólne tendencje i to, co należałoby w danym momencie czynić. Spora część migrantów mówi o tym, że nauczyła się po prostu ignorować wszelkie zachowania Brytyjczyków, które są dla nich dziwne i niezrozumiałe. Osoby, które mają problem z różnicami kulturowymi, wskazują na inną mentalność tych ludzi - odmienny pogląd na życie. Wynikają $\mathrm{z}$ tego pewne problemy $\mathrm{w}$ zrozumieniu siebie nawzajem, integracji i współpracy. Może to przyczyniać się do życia nie ze sobą, lecz obok siebie, w dwóch różnych światach, a poprzez te różnice nigdy nie zdoła się zrozumieć Brytyjczyków. 
Brak chęci do zamieszkania w tym miejscu na stałe nie idzie $\mathrm{w}$ parze $\mathrm{z}$ deklaracjami na temat przyjęcia obywatelstwa brytyjskiego. Aż 60 proc. migrantów wybrałoby to obywatelstwo, jeśli to pomogłoby im w uzyskaniu lepszej pracy czy poprawiło ich warunki bytowe. To spory odsetek jak na grupę ludzi, która nie ma zamiaru osiąść w tym miejscu na stałe. 20 proc. ankietowanych osób nie przyjęłoby obywatelstwa brytyjskiego, a 20 proc. zgodziłoby się na nie tylko, gdyby to pomogło im w naprawdę znaczący sposób zmienić sytuację życiową.

Mówiąc o plusach i minusach życia w Edynburgu, Polacy, jako największe zalety, uważają kolejno: zarobki (80 proc.), łatwiejsze życie (8 proc.), dostępne miejsca pracy (8 proc.), piękne położenie (4 proc.). Jeśli chodzi o minusy, to $\mathrm{ku}$ zdziwieniu na pierwszym miejscu nie znalazła się tęsknota za ojczyzną czy bliskimi (30 proc.), lecz pogoda (68 proc.), a na ostatnim miejscu - rosnące koszty utrzymania (2 proc.). W tym kontekście można przytoczyć takie komentarze: „Co z tego, że ogromnym plusem tego miasta jest bliskość zarówno gór, jak i morza, skoro śmiesznym minusem jest deszczowa pogoda". Można zauważyć też pewną zależność. Mianowicie dla osób, które wyemigrowały wraz $\mathrm{z}$ najbliższymi, największym minusem jest pogoda. W przypadku osób pozostawiających rodzinę w Polsce to odległość od domu i tęsknota. Stąd wyłania się kolejna zależność powodująca, że coraz więcej osób sprowadza do siebie swoich bliskich.

Jedna piąta ankietowanych migrantów uważa, że po wyjeździe z Polski nie musiała dostosować się do nowych realiów w jakiś szczególny sposób. Znacząca większość jednak mówi o konieczności poznania języka czy choćby osłuchania się z lokalnym dialektem, poznania prawa. Jak stwierdza jeden $\mathrm{z}$ migrantów: „Należy poznać nie tylko prawo spisane, ale też zasady niepisane, którymi się tutaj rządzą; nauczyć, że jesteśmy gośćmi w tym kraju, nie gospodarzami”. Kolejny dodaje: „Wielu rodaków nie powinno tutaj mieszkać, ponieważ nie potrafią się zachować i przynoszą wstyd naszemu państwu za granicą". Równomiernie rozkładają się odpowiedzi dotyczące dyskryminacji ze względu na pochodzenie. Występują głosy, że Szkoci ze swej natury nie szukają konfliktów, głęboko skrywają swoje prawdziwe odczucia. Z drugiej strony, wiele osób spotkało się $\mathrm{z}$ jawnymi przykładami dyskryminacji, obelgami, gorszym traktowaniem. Pojawiają się opinie, że początkowo skrywana dyskryminacja, zamieniła się $\mathrm{w}$ jawne obnoszenie się $\mathrm{z}$ nią. Jeden z uczestników wywiadu wspomina słowa swojego szefa, jednoznacznie wyrażające negatywny stosunek do zatrudniania kolejnych pracowników z Polski, mimo iż brakowało rąk do pracy.

Pytając o relacje Polaków w Szkocji, otrzymano wyniki sugerujące, że opierają się one głównie na rywalizacji (72 proc.); na pomoc stawia znacznie mniejsza grupa (28 proc.). Niektórzy, wahając się, skłaniają się jednak ku rywalizacji, thumacząc, że determinują ją finanse oraz to, iż każdy zdany jest tu przede wszystkim na siebie. Występują opinie, mówiące o trudnościach we współpracy z rodakami, zazdrości o pozycję zawodową, konfliktach, szczególnie teraz, kiedy coraz trudniej o pracę, a napływa tam wciąż sporo Polaków. Cytując jednego z uczestników wywiadu: „Nieważne, czy ktoś osiągnie awans ciężką pracą, poszczęści mu się, czy po prostu będzie lepszy od innych, przez rodaków bardzo często przemawia zazdrość i kiedy mogą, podkładają sobie przysłowiowe świnie". Kolejny zauważa, że pomoc owszem występuje, ale w małym gronie, głównie rodziny. Jednak jest to wsparcie chwilowe, na starcie, czy w trudnych chwilach.

Czynnikiem przyciągającym migrantów do Zjednoczonego Królestwa jest na pewno duża pomoc oferowana rodzinom $\mathrm{z}$ dziećmi oraz uczniom. Według Ministerstwa Pracy i Polityki Społecznej, w roku 2007 aż 55 tysięcy polskich dzieci pobierało zasiłki unijne, $\mathrm{z}$ tego połowa napływała $\mathrm{z}$ Wielkiej Brytanii i Irlandii (Iglicka 2008). Połowa ankietowanych migrantów w Szkocji otrzymuje pomoc w postaci zasiłków na dzieci, bądź dopłat do edukacji. Osoby te doceniają otrzymaną pomoc, dzięki której, jak mówią, żyje się bezpieczniej. Według artykułu z maja 2011 roku, spośród obcokrajowców w samej Szkocji, Polki urodziły najwięcej, bo aż 53 tysiące dzieci. Matki Polki królują w rankingach również w innych częściach Zjednoczonego Królestwa, jak np. w Walii - 14 tysięcy, Irlandii Północnej 
- 15 tysięcy, Londynie - 123 tysiące (Rogers 2011). Druga połowa migrantów deklaruje, że nie otrzymuje żadnej pomocy i jest zdana wyłącznie na siebie. W grupie tej znajdują się przede wszystkim osoby stanu wolnego.

Biorąc pod uwagę perspektywę powrotu do Polski, w grupie ankietowanych migrantów w Londynie większość (51 proc.) nie wie czy wróci. Powrót do Polski deklaruje 26 proc., natomiast 23 proc. nie ma tego w planach (Iglicka 2008). Odnosząc się do innych ankiet, $\mathrm{w}$ grupie migrantów $\mathrm{z}$ różnych części Wielkiej Brytanii, 7 proc. zamierza wrócić $\mathrm{w}$ przeciągu roku, 13 proc. $\mathrm{w}$ ciągu kilku lat, powrót $\mathrm{w}$ nieskonkretyzowanej przyszłości deklaruje 25 proc., 13 proc. nie chce wrócić, a 42 proc. nie zdecydowało jeszcze w tej kwestii (Milewski, Ruszczak-Żbikowska 2008). Polacy w Edynburgu, w przeważającej części (około 60 proc.), nie planują na razie powrotu, argumentując, że nie mają tam po co i do czego wracać. Część z nich uzależnia to od zgromadzenia odpowiedniego kapitału, by rozpocząć własną działalność w Polsce, a niektórzy $\mathrm{z}$ nich (16 proc.) planują migrację do innych krajów, jak Austria czy Niemcy. Jedna osoba utrzymuje, że wróci za rok bądź dwa, reszta deklaruje, że wróci na emeryturze. Pozostali nie wiedzą. Podkreślenia wymaga pewna prawidłowość, którą można dostrzec wśród migrantów w Edynburgu. Do podobnych wniosków dochodzą autorzy badania nad Polonią w Wielkiej Brytanii. Chodzi mianowicie o zależność mówiącą o tym, że osoby, które wyemigrowały niedawno, oceniają długość swojego pobytu na emigracji na kilka lat, nie dłużej. Jednakże wraz z coraz dłuższym przebywaniem za granicą, decyzja o powrocie jest odwlekana. W grupie ankietowanych $\mathrm{z}$ różnych części Zjednoczonego Królestwa, którzy mieszkają tam nie mniej niż 5 lat, 27 proc. osiedliło się na stałe (Milewski, Ruszczak-Żbikowska 2008). Jak już wcześniej wspomniano, nikt $\mathrm{z}$ uczestników wywiadów w Edynburgu nie wyraża chęci osiedlenia się tam na stałe, jednakże sporo $\mathrm{z}$ nich przebywa tam już od kilku lat i nic nie wskazuje na to, aby ta sytuacja miała ulec zmianie. Spora część obu grup mówi o tym, że wolałaby mieszkać w Polsce, a czynnikiem zatrzymującym ich w Wielkiej Brytanii są zarobki, możliwość życia na wyższym poziomie. Niektórzy z nich zbierają pieniądze na zakup mieszkania w Polsce, rozpoczęcie działalności gospodarczej lub zabezpieczenie finansowe w przypadku powrotu do ojczyzny.

Pytając o poczucie przynależności narodowej, otrzymano wyniki świadczące o tym, że większość migrantów wciąż czuje się przede wszystkim Polakami (52 proc.). Kolejna grupa uważa się na pierwszym miejscu za Europejczyków (40 proc.), a ostatnia - za obywateli świata (8 proc.). Nikt z zapytanych nie definiuje siebie, jako Brytyjczyka, czy Szkota. Występuje zależność, według której migranci, którzy przybyli stosunkowo niedawno uważają siebie za Polaków, ale wraz z coraz dłuższym pobytem, zaczynają czuć się przede wszystkim obywatelami Europy.

Najtrudniejszym pytaniem dla migrantów okazało się wskazanie, w jaki sposób okazują swoją więź z ojczyzną. Wyniki przedstawiają dosyć pesymistyczny obraz. Mianowicie, najczęściej udzielane odpowiedzi to brak jakichkolwiek więzi z Polską, ograniczanie ich tylko do kontaktów z bliskimi, przyjazdów do ojczyzny, monitorowania informacji z kraju. Kilka osób deklaruje śledzenie wiadomości z kraju, współodczuwanie z rodakami, odczuwanie emocji związanych np. $\mathrm{z}$ meczami polskich drużyn. Wiele osób wskazuje na to, że ciężko jest zachować poczucie własnej narodowości bez pewnych miejsc, przypominających o tym. Kościół wskazywany jest jako jedno $\mathrm{z}$ takich miejsc. Niestety nie występuje zbyt wiele inicjatyw łączących rodaków, co przyczynia się w pewien sposób do zatracania polskości wśród migrantów. Przy okazji wskazuje się na małą pomoc konsulatu w inicjowaniu i realizacji programów, pomagających integrować migrantów w Edynburgu. Jeden z migrantów wskazuje na większą integrację Polaków w innych częściach Szkocji, jak np. w znanym Klubie Sikorskiego w Glasgow. Migranci, szczególnie ci, którzy nie znają języka w sposób komunikatywny, wykazują większą potrzebę uczęszczania do miejsc zrzeszających Polonię, niż osoby posługujące się językiem angielskim, otaczające się nie tylko Polakami, ale i utrzymujące towarzyskie kontakty z przedstawicielami innych narodowości. 
Uczestnicy wywiadu jeżdżą do Polski średnio dwa razy w roku. Odpowiedzi wahają się w granicach od zera do czterech, ponieważ niektórzy nie odwiedzają ojczyzny każdego roku. Nie jest to duża liczba, jednak należy wziąć pod uwagę to, że dzięki tanim liniom lotniczym, to bliscy z Polski zaczynają częściej odwiedzać migrantów za granicą, niż oni sami przyjeżdżać do ojczyzny.

W raporcie z 2006roku, pt. „Polscy migranci w Londynie - klasa społeczna i etniczność", przeprowadzonym przez instytut CRONEM (Centre for Research on Nationalism, Ethnicity and Multiculturalism), przy Uniwersytecie Roehampton i Uniwersytecie of Surrey, który sfinansowała brytyjska Rada Badań SpołecznoEkonomicznych, podjęto próbę podziału wyjeżdżających ze względu na ich strategię migracyjną. Autorami tego raportu są prof. John Eade, dr Stephen Drinkwater oraz dr Michał P. Garapich. Podstawą tych badań była analiza jakościowych badań terenowych. W tym wypadku były to wywiady i obserwacje dotyczące tego, w jaki sposób Polonia w Londynie zapatruje się na kwestie etniczności, klasy społecznej, strategii w życiu i społecznych relacji. Badania oparto również na brytyjskich danych statystycznych. Wydzielono $w$ ten sposób 4 grupy. Pierwsza grupa to „bociany”. W jej skład wchodzą migranci sezonowi, którzy chcą w jak najkrótszym czasie zarobić jak najwięcej, nie wydając przy tym zbyt wiele. Cechy charakterystyczne tego grona to przebywanie za granicą od dwóch do sześciu miesięcy, poruszanie się w szeregach Polonii (ze względu na powiązania, dzięki którym mogą migrować tam sezonowo), zatrudnienie $\mathrm{w}$ niskopłatnych branżach (Drinkwater, Eade, Garapich 2006). W wywiadzie przeprowadzonym w Edynburgu, jedną z osób można uznać za członka tejże grupy. Złudnym jest wrażenie, że skoro to tylko jedna osoba, to pewnie kategoria „bocianów” nie jest popularna w Szkocji. Sytuacja jest inna albowiem wywiady przeprowadzone zostały w okresie świątecznym, zatem migranci sezonowi zdecydowali się $\mathrm{w}$ tym momencie na powrót do Polski. Natomiast większą liczbę „sezonowców” spotyka się w wakacje. Do grupy tej zalicza się na przykład studentów, przyjeżdżających w wakacje, czy rolników, którzy wyjeżdżają w okresie jesienno-zimowym. Postęp techniczny ułatwia tej grupie sprawne przemieszczanie i podtrzymuje praktyki sezonowe. „Bocian” z Edynburga deklaruje regularne wyjazdy od 2004 roku. Początkowo jego migracja trwała dłuższy czas, lecz obecnie wynosi trzy miesiące rocznie. Jest to okres intensywnej pracy, kumulacji zarobionych pieniędzy, pomieszkiwania u rodziny, przebywającej w Edynburgu, co idealnie wpisuje się w charakterystykę tejże grupy. Osoby z tej grupy odpowiadając na pytania o asymilację, integrację lub różnice kulturowe, nie potrafią wyrazić swojej opinii, ponieważ tak naprawdę ich pobyt to nieustanna praca i wyczekiwanie na rychły powrót do Polski.

Kolejna wyróżniona grupa to „chomiki”, które dążą do zgromadzenia funduszy podczas jednego dłuższego pobytu, aby $\mathrm{w}$ ten sposób móc otworzyć w Polsce własną działalność. Ci również wybierają niskopłatne branże zatrudnienia (Drinkwater, Eade, Garapich 2006). Zaklasyfikowanie migrantów w Edynburgu do tejże grupy sprawia nieco większy problem, ponieważ obok osób, które tylko akumulują kapitał, by wykorzystać go w Polsce, znajdują się również tacy, którzy robią to niejako pośrednio, nie czyniąc $\mathrm{z}$ tego celu samego w sobie. Zatem do grupy typowych „chomików” można wytypować cztery osoby, które uzależniają swój powrót do ojczyzny od zgromadzenia wystarczająco dużej ilości pieniędzy. Jednakże w miarę upływu czasu, kwota docelowa zaczyna się zwiększać, a wyjazd oddalać. „Chomiki” świadomie rezygnują $\mathrm{z}$ integracji ze społeczeństwem i nowym otoczeniem, ponieważ to dla nich tylko dodatek do pracy i zarobku, który ma ich „uwolnić” od losu większości rodaków w kraju, jak też postawić na uprzywilejowanej pozycji po powrocie.

Kolejna kategoria to „buszujący”. Nie ograniczają swoich planów do jednego kraju, są otwarci i gotowi na różne opcje. Znajdują zatrudnienie $\mathrm{w}$ różnych branżach. Ze względu na to, że grupa ta jest stosunkowo młoda wiekowo, wykazuje dużą mobilność międzynarodową, uważając, że europejski rynek pracy stoi przed nimi otworem (Drinkwater, Eade, Garapich 2006). Wśród uczestników wywiadu w Edynburgu, można zaklasyfikować do tej 
grupy sześć osób. Są to osoby, które zarówno migrowały wcześniej do innych krajów, jak i mają zamiar ponownie zmienić miejsce pobytu. Posiadają one dobrą znajomość języków, specjalizują się w jednym zawodzie, który przynosi im dobre zarobki, zatem zmiana miejsca pobytu nie wiąże się u nich z ryzykiem utraty pracy na dłuższy czas.

Ostatnia grupa to „łososie”, które albo osiedlą się na stałe, albo wrócą do Polski dopiero na starość. W tej grupie panuje pogląd, że będąc w Wielkiej Brytanii, można zdobyć więcej i żyć lepiej. Zatem mobilność ogranicza się do części Zjednoczonego Królestwa (Drinkwater, Eade, Garapich 2006). Siedmioro migrantów z Edynburga przynależy do tej właśnie grupy. Chodzi o osoby, które zamierzają powrócić do Polski na starość, ponieważ, jak wykazano wcześniej, nikt z uczestników wywiadu nie chce pozostać w Szkocji na stałe. Pozostali należą do grup pośrednich, ponieważ łączą cechy kilku grup i nie można ich zaklasyfikować jednoznacznie do jednej z nich.

Mówiąc o Polonii w Wielkiej Brytanii, nie sposób nie wspomnieć o rodakach, zamieszkujących tereny wiejskie. Tam, najczęściej $\mathrm{w}$ branżach związanych $\mathrm{z}$ przetwórstwem, pakowaniem i dystrybucją żywności, Polacy zapełniają nisze na rynku pracy. Określono ich tam mianem „ocalenia dla lokalnych rynków” (Fihel, Piętka 2007). Należy podkreślić, że polscy imigranci są niezbędni dla brytyjskiej gospodarki. Są bardzo elastyczni i znajdują zatrudnienie $\mathrm{w}$ rozmaitych dziedzinach, w których brakuje chętnych do pracy wśród Brytyjczyków. Prężna gospodarka opiera się w dużej mierze na imigrantach, którzy są dobrymi i rzetelnymi pracownikami, starającymi się wykonywać swoją pracę jak najlepiej, ponieważ nawet pracując za najniższą stawkę, mają poczucie, że są dobrze wynagradzani. Nierzadko rodacy przeliczają swoje zarobki na złotówki, co przyczynia się do tego, że nie dążą do awansu zawodowego, ponieważ uważają, że taki stan rzeczy i tak jest dobry, lepszy niż w Polsce.

Główne branże, które wybierali polscy migranci $w$ pierwszych latach po akcesji, to wśród mężczyzn: budownictwo (19,1 proc.), hotelarstwo i gastronomia (10,9 proc.), transport i turystyka (9,6 proc.), produkcja żywności i napojów ( 8,2 proc.). W przypadku kobiet najczęściej były to hotele i restauracje (14,1 proc.), służba zdrowia i praca socjalna (12,6 proc.). Najwięcej migrantów podjęło pracę fizyczną, która nie wymaga kwalifikacji (41,6 proc.). Pracownicy nie w pełni wykwalifikowani stanowili 33,2 proc., kadra szczebla średniego to 14,9 proc., a stanowiska kierownicze i profesjonalne objęło 10,4 proc. (Fihel, Piętka 2007). W grupie migrantów $\mathrm{w}$ Edynburgu znajdują się osoby, pracujące $\mathrm{w}$ różnych zawodach. Jednak najwięcej kobiet (40 proc.) pracuje w hotelarstwie, bądź jako pomoc domowa. Wśród mężczyzn jest to najczęściej posada ochroniarza (20 proc.), kierowcy (20 proc.) oraz tak zwanej ,złotej rączki" (10 proc.). Pojawiają się także takie zawody, jak: manager restauracji, fryzjer, sprzedawca, porządkowy. Występuje pewna zależność, według której najlepsze posady posiadają migranci, którzy przybyli tam najwcześniej. W grupie uczestników wywiadów dominują osoby, które pracują od początku swojego przyjazdu w tym samym miejscu (70 proc.).

Mówiąc o wizerunku Polaków w Wielkiej Brytanii, należy spojrzeć na tę kwestię z dwóch stron. Z jednej, Polacy uważani są za pracowitych i zdeterminowanych, niebojących się żadnej pracy. Z drugiej zaś, zamienia się to w obraz Polaka - osoby stworzonej do wykonywania prostych prac, który niekoniecznie pasuje do stanowisk wyższych, wymagających wykształcenia. Polaków zadowala praca, której Brytyjczycy nie chcą podjąć, co przyczynia się do degradacji zawodowej. Występuje zjawisko brain waste - marnotrawstwa mózgów, które najlepiej obrazuje fakt, że jedna trzecia młodych migrantów z Polski, ma wyższe wykształcenie, lecz spora część pracuje poniżej swoich kwalifikacji, na przykład, jako magazynierzy czy kelnerzy (Bera, Korczyński 2012). Brytyjczycy nierzadko dziwią się, kiedy okazuje się, że Polacy znają się na komputerach, są wykształceni, aspirują do zajmowania wyższych stanowisk. Często traktuje się ich jak podrzędnych pracowników, stworzonych do tego, by wykonywać pracę fizyczną. W pewnej mierze sami Polacy są winni temu, że są tak postrzegani. 
Zdarza się, że pierwsza otrzymana po przyjeździe praca, staje się stałą pracą. Rodacy pracują za tę samą najniższą stawkę, zwiększając jedynie liczbę przepracowanych godzin. Z drugiej strony, istnieje oczywiście grupa rodaków, która poprzez uczęszczanie na kursy, naukę języka i wszelkie inne starania, dąży do awansu zawodowego. Osoby starsze trudno przekonać do rozpoczęcia nauki języka, mimo iż nie brak im motywacji. Uważają, że nie poradzą sobie, albo, że jest im to zbędne, ponieważ już posiadają pracę. Po rozmowie $z$ nauczycielką języka angielskiego z Edynburga, która prowadzi kursy dla rodaków, dochodzi się do pesymistycznych wniosków. Wprowadzenie kursów bezpłatnych, czy za uiszczeniem symbolicznej opłaty, spowodowało efekt odwrotny od zamierzonego. Polscy migranci stwierdzili, że skoro kursy są darmowe, to zapewne nie przynoszą żadnych efektów. W odpowiedzi szkoły otrzymały odpowiedź, że szkoda czasu na takie kursy, ponieważ można w tym czasie pracować.

Stereotypy o Polakach są nadal zauważalne w społeczeństwie brytyjskim. Większość sugeruje się doniesieniami prasowymi, które przedstawiają Polonię w bardzo zróżnicowany sposób. Jeśli chodzi o ocenę imigrantów, to Polacy plasują się na czwartym miejscu, zaraz po migrantach z Australii, Francji i Kanady. Wśród pracoholików zajmujemy pozycję drugą po Amerykanach. Polaków uważa się za ludzi ciężko pracujących, którym można zaufać i którzy wykonują swoje obowiązki najlepiej, jak potrafią (Bera, Korczyński 2012). Z drugiej strony, stereotyp Polaka cwaniaka i złodzieja, który nadużywa pomocy socjalnej, wciąż istnieje. Podsycane jednostkowymi zdarzeniami kradzieży czy wandalizmu, media formułują zastrzeżenia do ogółu polskich migrantów. Uważa się, że Polacy to wręcz fundamentaliści religijni i rasiści. Duża religijność rodaków uważana jest często za wadę, prymitywność i zacofanie. Przez sporą część Brytyjczyków przemawia typowa zazdrość, kiedy okazuje się, że migranci okazują się lepszymi pracownikami, bądź zajmują ich stanowiska.

\section{Podsumowanie}

Liczne migracje niosą za sobą szereg niebezpieczeństw dla funkcjonowania państw emigracyjnych, takich jak Polska. Wyjazdy młodych ludzi przyczyniają się do starzenia się społeczeństwa oraz problemów w działaniu systemu emerytalnego. Według Eurostatu, w 2060 roku w Polsce będzie występował największy odsetek ludzi po 65. roku życia, a co trzeci Polak będzie emerytem. Liczba ludności wynosić będzie około 31 milionów. Prognozy te powstały w oparciu o analizy umieralności, płodności i jej zmian. Nie wzięto pod uwage jednak migracji poakcesyjnych, zatem sytuacja może jawić się jeszcze bardziej niekorzystnie (Iglicka 2011). Migracje powodują odpływ dobrych specjalistów, których braki są dla państwa szczególnie odczuwalne i mogą hamować rozwój gospodarki. Jeśli chodzi o negatywny wpływ na rodziny emigracyjne, to można wskazać na coraz częstsze rozwody. Prognozy mówią o tym, że przy aktualnym tempie rozwodów w Polsce, może rozpaść się co trzecia rodzina emigracyjna. Kolejny problem to eurosieroctwo, szacowane na poziomie od 45 do 110 tysięcy dzieci, których jedno bądź oboje rodziców wyjechało. Eurosieroty są bardziej podatne na depresję, częściej sięgają po narkotyki i alkohol, mają problemy w szkole (Bera, Korczyński 2012).

Wielka Brytania to, mimo upływu lat, wciąż bardzo atrakcyjne miejsce migracji dla Polaków. Rodacy udowodnili, że potrafią pokonać różne przeciwności i poradzić sobie w nowym miejscu, tak bardzo różniącym się od ich ojczyzny. Niestety dużym minusem strategii migracyjnej Polaków jest to, że często unikają podnoszenia kwalifikacji i nie próbują awansować. Trzymają się kurczowo tego, co zastali po przybyciu. Zrozumiałym jest, że zaraz po przyjeździe przyjmowali niemal każdą pracę, która pozwoliła im stać się niezależnymi finansowo. Jednakże w miejscu tak dużych możliwości, gdzie na wyciągnięcie ręki jest oferta dokształcania $\mathrm{i}$ inwestowania $\mathrm{w}$ siebie oraz dostępność wielu interesujących i dobrze płatnych etatów, warto wykorzystać tę szansę. Powodem takiego stanu rzeczy może być to, że migranci wyjeżdżając, uważają, że pobyt 
w nowym miejscu to tylko okres przejściowy, a nie nowy rozdział w ich życiu. Często okazuje się jednak, że sytuacja zmusza ich do pozostania na emigracji przez wiele lat. Jeśli chodzi o ocenę swojego pobytu, migranci po początkowych negatywnych odczuciach i nieustannym oczekiwaniu na szybki powrót do ojczyzny, zmieniają zdanie na bardziej przychylne w stosunku do nowego miejsca zamieszkania (Kubitsky 2012). Poczucie dobrego wynagrodzenia, bez obawy o jutro, staje się bezpieczną stabilizacją, którą ciężko osiągnąć w Polsce. Decyzja o powrocie zamienia się $\mathrm{w}$ decyzję o ściągnięciu do siebie najbliższych i rozpoczęciu nowego życia na emigracji. Wśród uczestników wywiadu w Edynburgu, aż 80 proc. uznało Szkocję za miejsce przyjazne dla migrantów. Tylko nieliczni $\mathrm{z}$ nich podjęli decyzję o powrocie w ciągu najbliższych lat, natomiast większość traktuje Wielką Brytanię, jako swoje miejsce pobytu, w którym prowadzą normalne życie, gdzie nie tylko pracują i gromadzą fundusze na powrót do Polski. Znaleźli się i tacy, którzy mimo długiego pobytu na emigracji, wciąż żyją wyłącznie perspektywą powrotu, nie integrują się i po prostu egzystują, zbierając kapitał na powrót do życia w Polsce.

Migrantów z Edynburga na tle Polonii w Wielkiej Brytanii wyróżnia to, że patrzą dosyć realnie na perspektywę swojego powrotu, nie rządzą nimi sentymenty związane z krajem ojczystym, jak też charakteryzuje ich otwartość na świat i nowe perspektywy. Widzą w sobie Europejczyków, dla których cały kontynent stoi otworem, zatem każdy inny kraj może stać się ich nowym domem. Zdają sobie sprawę, że Szkocja to część Wielkiej Brytanii, która jest miejscem przyjaznym dla migrantów, dlatego też napływa tam coraz więcej Polaków z innych części Zjednoczonego Królestwa, a ci, którzy przybyli tam po 2004, postanawiają pozostać na dłużej. Cechuje ich wysoka świadomość celów działania, która uwidacznia się już poprzez sam wybór miejsca innego, niż większość rodaków. Polacy znają swoje prawa i ubiegają się o świadczenia, które im się należą i nie dają się zepchnąć na boczny tor. Chętnie korzystają z różnych kursów, które pozwalają im otrzymywać lepsze propozycje pracy. To już nie tylko pracownicy fizyczni, lecz wykształceni managerowie i pracownicy urzędów, którzy radzą sobie nie gorzej niż rodzimi mieszkańcy. Migranci z Polski w Edynburgu postanawiają uczestniczyć w życiu społecznym, nie zamykać się w gronie Polonii. Otwierają dobrze prosperujące restauracje, sklepy, biura. Dają tym samym sygnał społeczności lokalnej, która w pewnej mierze zaczyna obawiać się ich potencjału. Udowadniają, że potrafią radzić sobie i dostosować się do nowych warunków życia.

\section{Literatura:}

Bera, R., Korczyński, M. (2012). Dynamika migracji Polaków do Wielkiej Brytanii po wstąpieniu Polski do Unii Europejskiej. W: H. Kosienkowska (red.), Dystans społeczny emigrantów polskich wobec obcych i innych. Lublin: Wydawnictwo UMCS.

Drinkwater, S., Eade, J., Garapich, M. (2006). Polscy migranci w Londynie - klasa społeczna i etniczność. Center for Research on Nationalism, Ethnicity and Multiculturalism, University of Surrey.

Fihel, A., Piętka, E. (2007). Funkcjonowanie polskich migrantów na brytyjskim rynku pracy. CMR Working Papers 23, Warszawa: Ośrodek Badań nad migracjami UW.

Główny Urząd Statystyczny (2011). Informacja o rozmiarach i kierunkach emigracji z Polski w latach 2004 - 2010. Warszawa.

Iglicka, K. (2008). Czy naprawdę Anglia to raj? Badanie nad legalnymi migracjami zarobkowymi z Polski do Wielkiej Brytanii po 1 maja 2004. W: K. Goldbergowa (red.), Kontrasty migracyjne Polski. Wymiar transatlantycki. Warszawa: Wydawnictwo Naukowe Scholar.

Iglicka, K. (2011). Migracje dtugookresowe i osiedleńcze z Polski po 2004 roku-przyktad Wielkiej Brytanii. Wyzwania dla statystyki i demografii państwa. Warszawa: Centrum stosunków międzynarodowych.

Kubitsky, J. (2012). Psychologia migracji. Warszawa: Wydawnictwo Difin. 
Lewandowski, Ł. (2010). Życie i praca Polaków w Wielkiej Brytanii. W: I. Sobczak (red.), Współczesne migracje ludności w Polsce - uwarunkowania i skutki. Gdańsk: Wydawnictwo Gdańskiej Wyższej Szkoły Administracji.

Milewski, M., Ruszczak-Żbikowska, J. (2008). Motywacje do wyjazdu, praca, więzi społeczne i plany na przyszłość polskich migrantów przebywajacych w Wielkiej Brytanii i Irlandii. CMR Working Papers 35. Warszawa: Ośrodek Badań nad migracjami UW.

Rauziński, R. (2010). Migracje zagraniczne Polaków w XX i XXI wieku w świetle badań demograficznych. W: A. Lipski, W. Walkowska (red.), Emigracja jako problem lokalny i globalny. Mysłowice: Wydawnictwo Górnośląska Wyższa Szkoła Pedagogiczna im. Kardynała Augusta Hlonda.

Rogers, S. (2011). The UK's foreign-born population: see where people live and where they're from. Pobrano 25.02.2013 z: http://www.guardian.co.uk/news/datablog/2011/may/26/foreign-bornuk-population?intcmp=239\#_,26.05.2011 . 